\title{
Nasal Cavity and Paranasal Sinuses Cancer Pathologic TNM Finding v8
}

National Cancer Institute

\section{Source}

National Cancer Institute. Nasal Cavity and Paranasal Sinuses Cancer Pathologic TNM

Finding v8. NCI Thesaurus. Code C133026.

A pathologic finding about one or more characteristics of nasal cavity and paranasal sinuses cancer, following the rules of the TNM AJCC v8 classification system. 